\title{
STUDA BBLLCA
}

Since 1971, Studia Biblica et Theologica has provided opportunity for students interested in the scholarly pursuit of biblical and theological topics to publish their work. SBT seeks not only to provide a stimulus to students by giving them a goal to aim for in their research, but aspires to contribute significantly to the basic fund of biblical and theological knowledge, thereby serving both the theological community and the Church.

$S B T$ invites students in seminaries and graduate schools of religion to submit quality essays in biblical studies, theology and related disciplines for consideration for publication. Essays must be written in English and conform to the "Instructions for Contributors" published in the Journal of Biblical Literature (95 [1976] 331-46). Manuscripts over 50pp. in length will not be considered. All manuscripts should be submitted in duplicate and become the property of $S B T$. Please direct articles to:
Prof. James E. Bradley
General Editor, SBT
Fuller Theological Seminary
135 N. Oakland Avenue
Pasadena, CA 91101 USA

Studia Biblica et Theologica is published twice yearly, in April and October, with each issue comprising approximately 72pp. $S B T$ is typeset, perfect bound and trimmed to $5 \frac{1}{2} \times 81 / 2$ inches. $S B T$ is indexed in Elenchus Bibliographicus Biblicus, Internationale Zeitschniftenschau für Bibelwissenschaft und Grenzgebiete and Old Testament Abstracts. Subscriptions to SBT are $\$ 5.00$ per year ( $\$ 6.00$ outside the USA). Multiple-year subscriptions for up to three years are accepted. All subscriptions must be prepaid. Please send order and payment (in US dollars) to: Gary A. Tuttle, Managing Editor, SBT, at the address noted above. 


\section{NOTES FOR GONTRIBUTORS}

Contributions and editorial correspondence should be sent to one of the editors: Rev. Dr A. I. C. Heron, New College, Mound Place, Edinburgh EHI 2Lx; Rev. Dr J. Houston, University of Glasgow, 3 Southpark Terrace, Glasgow G12 8QQ or to Scottish Academic Press Ltd., 33 Montgomery Street, Edinburgh EH7 5Jx.

Submission of an article is taken to imply that it has not previously been published in English, or is not being considered by another journal for publication in English. In the interests of authors, copyright is normally assigned to the Scottish Academic Press. The average length of articles is 5000 words. Although longer articles are accepted, those in excess of 10,000 words cannot be considered.

Contributions (articles and reviews) should be clearly typed in double spacing, and on one side of the paper only. The rule about double spacing applies also to footnotes, which should be used sparingly. Cross-references within the article offered should not be included.

Notes for the editors and instructions for the printer should be attached on separate sheets. Contributors should keep one copy of the typescript for use in correcting proofs.

Contributors from the United States may use U.S. spellings. Greek and Hebrew words need not be transliterated. Capitalisation should be kept to a minimum; and in particular should not be used in pronouns referring to the Deity.

First proofs of articles and reviews may be read and corrected by contributors, and should normally be returned to the organising editor within ten days of receipt. Correction should be confined to errors of the printer. More extensive correction can be made only with the concurrence of an editor. No proofs of reviews will be sent.

Contributors of articles and article reviews (but not of reviews) receive 10 free offprints. Extra copies may be bought according to an agreed scale of charges, provided that these are ordered at the time of returning corrected proofs.

\section{PERMISSIONS}

For permission to reproduce material from Scottish fournal of Theology please apply to the Scottish Academic Press, 33 Montgomery Street, Edinburgh EH7 5Jx. 


\section{SGOTTISH JOURNAL OF THEOLOGY \\ VOLUME 31 No. 3}

\section{GONTENTS}

The Spirit of Inquiry and the Reflected Self: Theological Anthropology and the Sociology of Knowledge, by Hugh JoNES

Jonathan Edwards on the Problem of Faith and History, by John PIPER

The Freedom of God in the Theology of Karl Barth, by George S. Hendry

The Sonship of the Historical Jesus in Christology, by RIGHARD BAUGKHAM

Regnum Dei Deus Est, by Bruge D. Chilton

\section{REVIEWS}

BUsch: Karl Barth. His Life from Letters and Autobiographical Texts LONERGAN: The Way to Nicea HOPPER: A Dissent on Bonhoeffer SANDERs: Ethics in the New Testament

JENkins: Christian Maturity and the Theology of Success

vinay: Le confessioni di fede dei Valdesi riformati

GRAHAM: Angels: God's Secret Agents

BLIDSTEIN : Honor thy father and mother-filial responsibility in Jewish law and ethics ROGERSON: The Supernatural in the Old Testament

kUske: The Old Testament as the Book of Christ: An Appraisal of Bonhoeffer's Interpretation
GARROLL: Transactions of the Glasgow University Oriental 271 Society, Vol. XXV (1973-4) 288

274 GUNDRY: Sōma in Biblical Theology

276 with Emphasis on Pauline Anthropology 288

279 schmemann: Of Water and Spirita Liturgical Study of Baptism 291

280 ANDERSON: The Gospel of Mark $29^{1}$ 282 MARTin: Philippians 293 EDWARDS: A Concordance to $Q \quad 295$ 283 szóvérfry: Peter Abelard's Hymnarius Paraclitensis. I: Introduction to Peter Abelard's 284 Hymns. II: The Hymnarius Paraclitensis; Text and Notes 295 285 MORRIS: Cholera $1832 \quad 296$ WARD: Friday Afternoon 298 287 PARRINDER: Jesus in the Qur'an 299

(C) Scottish Academic Press Ltd. 1978

Printed in Great Britain by R. \& R. Clark, Ltd., Edinburgh 